\title{
ISSUES IN SECOND LANGUAGE ACQUISITION RESEARCH AND THE RELATION WITH NATIVE-LIKE COMPETENCE
}

\author{
Riana Agustin Tindjabate \\ Universitas Kristen Tentena
}

\begin{abstract}
This research reviews the relevancy of native-like competence in SLA study. It is used three issues that mostly found in English teaching. The first issue which always occurs in the discussion of learning English is communication needs between native speakers and L2 learners. Secondly, it is the domination of pragmatic aspect. The third issue is about teaching of target culture. Research results reveal that most of L2 learners are not accustomed to the full range of styles, structures, and speech acts of the native speakers since English is not used as their daily language. The learners might have different comprehension with the native speaker about the use of particular English words, sentences or phrases. The learners must know how to communicate well with native speaker and non native speaker of English by using particular words, sentences or phrases in a particular place or occasion.
\end{abstract}

\section{Introduction}

In the present day, placing native-like competence as tool to compare second language learners (L2) and native speakers in SLA research is not relevant (Bley-Vroman in McKay, 2002:39). Sridhar and Sridhar have criticized it (McKay, 2022:39). To examine whether native-like competence is still or not relevant anymore in SLA research, in terms of L2 learners' context, we have to relate it with three issues encountered in English teaching.

\section{Research Methods}

This is a literature study of the issue in second language acquisition research and the relation with native-like competence. The researcher reads relevant theories and highlights important issues related to the second language acquisition research. The researcher then elaborates the issues with the facts that are found in classroom in order to introduce critical thinking on the Sridhar and Sridhar's statement about the native-like competence.

\section{Results}

The first issue which always occurs in the discussion of learning English is communication needs between native speakers and L2 learners. The teacher should be aware that students are not accustomed to the full range of styles, structures, and speech acts of the native speakers since English is not used as their daily language and is not meet all of their communication needs (McKay, 2002:40). For instance in Indonesia, it is not polite to call a teacher without mentioning her/ his full name whereas in the native speakers' context it is enough by mentioning the word "you" or the teacher's nickname if the relationship is close enough.

Because English cannot meet all L2 learners' communication needs, the students might have different comprehension with the native speaker about the use of particular English words, sentences or phrases. Although English has standards in grammar, 
phonology and lexicon but in the real communication, pragmatic aspect is more dominant. This second issue is strongly related to the meaningful conversation which involves the context of speech acts between the speaker and the hearer. The speaker hopes that the hearer will understand the intention he/ she is trying to say implicitly so that she/ he can get response from the hearer (Thomas in McKay, 2002:73).

The third issue is about teaching of target culture. To gain the ability such as knowing how to communicate well with native speaker and non native speaker of English by using particular words, sentences or phrases in a particular place or occasion, teachers should also emphasize their teaching materials and method on pragmatic competence and set aside the native speaker's model.

However, it does not mean that teaching target culture of the native countries is ignored. Some of the target culture can give positive input to L2 learner such as punctuality and queue. Besides that, there are several similarities between western culture and eastern culture like greetings. In my place, for instance, it has local tradition of greeting particular day which is similar with western culture. It is called Padungku. It has the same meaning with Thanksgiving Day celebrating in western countries, initially, expression of feeling grateful after harvest. My students have less understanding of what Thanksgiving Day meaning is, however, teaching the target culture by connecting it with their local tradition is helpful them to understand deeply the meaning certain target cultures. They are supported to reflect experiences and the things on their own culture in which they are directed to have an image of international culture. By having good comprehension on cross cultural aspects, students are able to develop their pragmatic competence and communication skills, particularly the competence and skills in using English as an international language.

Pragmatic competence of the native speaker is no longer the only basis of SLA research in measuring pragmatic competence of L2 learners because in inner circle countries themselves there are many different conversation styles. However the teachers can raise the pragmatic sense of the students by teaching target culture and connecting it with the source culture so that the students can have an image of international culture.

Discussing issues in SLA research and its relation to native-like competence, another important target of learners is having good rhetorical competence. To be able to communicate ideas through written text by using English, L2 learners have to express their ideas coherently in their written text. Teachers must realize that rhetorical competence of his/ her students is strongly influenced by their culture of learning. Ballard and Clanchy in McKay, 2002:107 said Asian culture of learning references to 'conserving knowledge' or knowledge of the past because the students are always asked to memorize and imitate in the process learning language. I used to experience this when I was in junior high school, memorization of vocabularies and repetition of dialogue were dominating my English class. Critical thinking is not available in the class so that it is difficult for the students to state main point or to go straightly to the point in their written assignment. As the result, many English teachers in eastern countries are difficult to understand their students' written text because it is twisting and worse, the main point is never stated. Kaplan (1966) found that there are different organizational patterns of cultural groups in their rhetorical competence.

The patterns show the difference among five cultural groups. Referring to this, if L2 learners want to communicate globally their ideas in the form of written text, many educators suggest L2 learner to adapt the native rhetorical competence which tends to be direct. This is a challenge to the teacher and the students from Asia countries whose learning process is more reproductive end and less of speculative end. Regarding to this issue, Western specialist has promoted communicative language teaching (CLT) as 
one of teaching method which not only encourage students to actively use English in communication but also to train them to develop actively their ideas through writing tasks. The communication styles of the native speaker in saying their ideas clearly and coherently through writing can be a positive input to the teachers in order to design teaching method which can improve students' writing skill.

In present day, CLT is very popular and used in many levels of language education; schools, higher education and language institution or courses. There are two versions of CLT: weak and strong version (McKay, 2001:108-109). A weak version of CLT focuses on speaking applied in group discussion and students' participation collectively whereas the strong version emphasizes on students communication with a text. They work with the others to solve problem and share ideas by using their mother tongue but later on they have to report the result in English. The weak version is applied mostly in private institution in Australia, Britain, and North America while the strong one is applied in public education system such as elementary school.

Unfortunately, the application of CLT, in Asian schools, is dominated by the weak version. The teacher focuses only on speaking skill rather than developing integrated skills which involve reading, writing and listening. Brown through his observation gives a view that those skills are interrelated one to each other (2001:233234). If the teacher wants to give chance to the students to explore knowledge by using the four skills, the integration is needed in this method which also can help the students to have enough rhetorical competence alongside the skills. The teachers might do the following ways, for example, giving relevant text to be read, encouraging students to use their critical thinking in solving the problems, facilitating them to speak English actively in group discussions by sharing their own opinion about the content of the text, asking them to report their work in English in the form of written report.

The learning culture of English native speaker is different with L2 learners who come from expanding circle countries. Because L2 learners study English as an International Language, modifying the weak and strong version of CLT in classroom in one good solution for teacher to anticipate problems and difficulties encountered and to meet students' needs on the language. By modifying the two versions of CLT, teachers do not only teach students how to speak English fluently but to think and share ideas critically through integrated learning process.

\section{Conclusion}

Although Sridhar and Sridhar might criticize that native-like competence is not relevant in SLA research, in fact, towards its relation with several issues we still can find the relevancy. We cannot learn English as an international language without learning and adapting the culture such as punctuality and queuing. To improve our communication skill and rhetorical competence, we use their teaching methodology even we are trying to follow their culture of learning and imitate their communication styles in learning. As the conclusion, native-like competence is still relevant in SLA research if we use it as an input for L2 learners not as standards of comparison.

\section{References:}

Lauder, Allan. 2008. The status and Function of English in Indonesia: A Review of Key Factors. Makara, Sosial Humaniora: Universitas Indonesia. Retrieved 3rd October 2011

Brown, Douglas H. 2001. Teaching by Principles. Second Edition. New York: Longman Inc.

http://eslbee.com. 2011. Advanced Composition for Non-Native Speakers of English. Retrieved on 1st of April 2011.

Ika, Grace and Harbon, Lesley. 2010. English Teachers Professionalism and 
Professional Deleopment. Some Common Issues in Indoensia. Asian EFL Journal. Retrieved 3rd October 2011.

McKay, Sandra Lee. 2002. Teaching English as an International Language. Oxford:OUP

Nurkamto, Joko. Problema Pengajaran Bahasa Inggris di Indonesia: Universitas Sebelas Maret Surakarta. Retrieved 3rd October 2011.

Suhendi, Andang. 2005. English Language Learners at the Faculty of Agriculture, Islamic Unievrsity of North Sumatra-Indonesia: Universiti Sains Malaysia. Retrieved 3rd October 2011.
Xiaorong, Yan and Lili, Zhai. 2010. The Application of Communicative Approach in Business English Teaching. The ESP Asian Journal. Retrieved 3rd October 2011.

Xiaorong, Yan and Lili, Zhai. 2010. The Application of Communicative Approach in Business English Teaching. The ESP Asian Journal. Retrieved 3rd October 2011.

Zacharias, Nugrahenny. T. 2003. A Survey of Tertiary Teachers' Beliefs About English Language Teaching in Indonesia with Regard to the Role of English as A Global Language. MA-ELT Thesis. Institute for English Language Education Assumption University of Thailand. Retrieved 3rd October 2011. 